\title{
Internet Usage in Urban-Rural area with e-Commerce and e-Banking
}

\author{
Numan Mohsin
}

\author{
Satya Prakash Mishra
}

\author{
Neeraj Sahu
}

\begin{abstract}
This paper present how the different users Internet usage in urban-rural area with e-commerce, and e-banking and these activities in remote areas, information technology might serve as a substitute for urban collection. We survey the technology comparison between the rural and urban we found the rural area users are not more aware but in urban area users are more aware and efficient use the technologies e- system so we are required the e-education in rural area The outcomes results shows in form of percentage of internet uses for village and district level and this results are efficient and accurate. These result calculated by numerical computational software MATLAB 7.14
\end{abstract}

\section{Keywords}

Internet, Rural, Urban, e-commerce, e-banking

\section{INTRODUCTION}

Internet, the every expanding technology, serves as one-stop point for all the needs of academic community, be it information, education, communication, or research. It provides access to galaxies of internet service round the clock (24X7) and sources at a click. These galaxies of internet service and sources have attracted a large number of people from all over the world towards the internet. According to internet World Statistics, the population of internet users worldwide is $42.4 \%$ of the world's population uses the Internet. According to the International Telecommunication Union about 3.2 billion people.

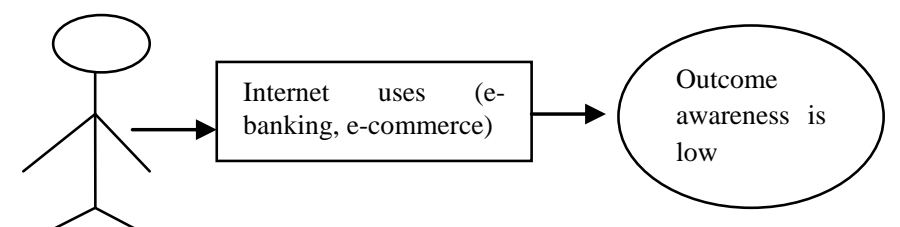

$$
\text { Rural Area }
$$

Figure 1: rural area users

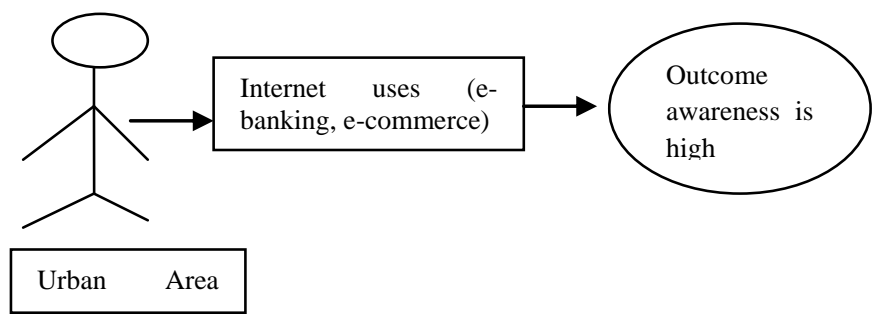

Figure 2: urban area users

\section{LITERATURE REVIEW}

In (2000) C.R.C.E. gave Secretele comerului electronic.Ghid pentru exportatori-întreprinderimici imijlocii, [4] ,In 2002 Bucur, C.M. gave Comer electronic [1],In 2002 Anghel, L.D. gave Business to business marketing [2].

In 2007 Gay, R. Charlesworth, A., Esen, R. gave Online marketing [3],In 2008. Lai, L.S.; Turban, E Groups gave formation and operations in the Web 2.0 environment and social networks [4].

In 2011 Anghelu, N., gave Comerul electronic [5], In 2012. Mâranu, R. gave Etapele Comerului electronic [6].

\section{RESEARCH METHODOLOGY}

In this paper we can use the research methodology in four steps:-

\subsection{Data Collection}

We collect the data from various resources just like social media banking transaction and various commercially organization. These data help to give various type data with electronic system.

\subsection{Data Analysis}

We analysis the data from various heterogeneous resources with rural and urban collection.

\subsubsection{Rural Analysis}

We analysis data from rural collection the awareness outcomes are less compare to urban collection.

\subsubsection{Urban Analysis}

We analysis data from urban collection the awareness outcomes are efficient and accurate compare to rural collection.

\subsection{Data Processing}

We process data from matlab 7.14 software with numerical percentage of computational then we see the rural collection accuracy of percentage is less then compare to urban data collection.

The accuracy is a measure of the degree calculated value to its actual value. The percent error is the ratio of the error to the actual value multiplied by 100 .

$$
\% \text { error }=\frac{\text { error }}{\text { actual value }} \times 100
$$

\subsection{Data Outcome}

We calculate \% error or accuracy percentage of rural and urban collection with the help of the formula is given data processing steps. The percentile of the accuracy calculated with numerical computational matlab 7.14 software. 


\section{EXPERIMENTAL RESULT}

We calculate the experimental result from randomly selected data set $S=\left\{d_{1}, d_{2}, d_{3}, \ldots \ldots . d_{n}\right\}$ Where $d_{1}, d_{2}, d_{3}, \ldots \ldots . d_{n}$ are randomly selected datasets. The datasets downloaded from very large UCI KDD datasets we select only 16 datasets

$d_{1}, d_{2}, d_{3}, d_{4}, d_{5}, d_{6}, d_{7}, d_{8}, d_{9}, d_{10}, d_{11}, d_{12}, d_{13}, d_{14}, d_{15}, d_{16}$

Table-1 Accuracy percentage for rural correction

\begin{tabular}{|c|c|c|}
\hline Datasets & $\begin{array}{l}\text { Frequency } \\
\text { datasets }\end{array}$ & $\begin{array}{l}\text { Accuracy } \\
\text { Percentage }\end{array}$ \\
\hline $\mathrm{d}_{1}$ & 50 & 48 \\
\hline $\mathrm{d}_{2}$ & 100 & 45 \\
\hline $\mathrm{d}_{3}$ & 150 & 43 \\
\hline $\mathrm{d}_{4}$ & 200 & 41 \\
\hline $\mathrm{d}_{5}$ & 250 & 38 \\
\hline $\mathrm{d}_{6}$ & 300 & 35 \\
\hline $\mathrm{d}_{7}$ & 350 & 32 \\
\hline $\mathrm{d}_{8}$ & 400 & 29 \\
\hline $\mathrm{d}_{9}$ & 450 & 27 \\
\hline $\mathrm{d}_{10}$ & 500 & 25 \\
\hline $\mathrm{d}_{11}$ & 550 & 24 \\
\hline $\mathrm{d}_{12}$ & 600 & 21 \\
\hline $\mathrm{d}_{13}$ & 650 & 19 \\
\hline $\mathrm{d}_{14}$ & 700 & 14 \\
\hline $\mathrm{d}_{15}$ & 750 & 13 \\
\hline $\mathrm{d}_{16}$ & 800 & 10 \\
\hline
\end{tabular}

Table-2 Accuracy percentage for urban correction

\begin{tabular}{|c|c|c|}
\hline Datasets & $\begin{array}{l}\text { Frequency } \\
\text { datasets }\end{array}$ & $\begin{array}{l}\text { Accuracy } \\
\text { Percentage }\end{array}$ \\
\hline $\mathrm{d}_{1}$ & 50 & 51 \\
\hline $\mathrm{d}_{2}$ & 100 & 48 \\
\hline $\mathrm{d}_{3}$ & 150 & 46 \\
\hline $\mathrm{d}_{4}$ & 200 & 44 \\
\hline $\mathrm{d}_{5}$ & 250 & 41 \\
\hline $\mathrm{d}_{6}$ & 300 & 38 \\
\hline $\mathrm{d}_{7}$ & 350 & 35 \\
\hline $\mathrm{d}_{8}$ & 400 & 32 \\
\hline $\mathrm{d}_{9}$ & 450 & 34 \\
\hline $\mathrm{d}_{10}$ & 500 & 31 \\
\hline $\mathrm{d}_{11}$ & 550 & 28 \\
\hline $\mathrm{d}_{12}$ & 600 & 25 \\
\hline $\mathrm{d}_{13}$ & 650 & 22 \\
\hline $\mathrm{d}_{14}$ & 700 & 17 \\
\hline $\mathrm{d}_{15}$ & 750 & 16 \\
\hline $\mathrm{d}_{16}$ & 800 & 13 \\
\hline & & \\
\hline
\end{tabular}

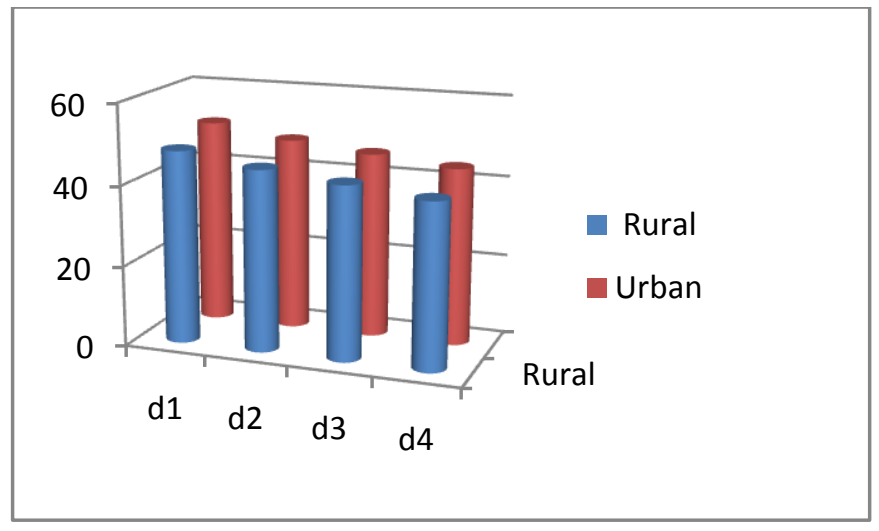

Figure 3: Describe accuracy percentage of rural and urban for dataset $d_{1}, d_{2}, d_{3}, d_{4}$

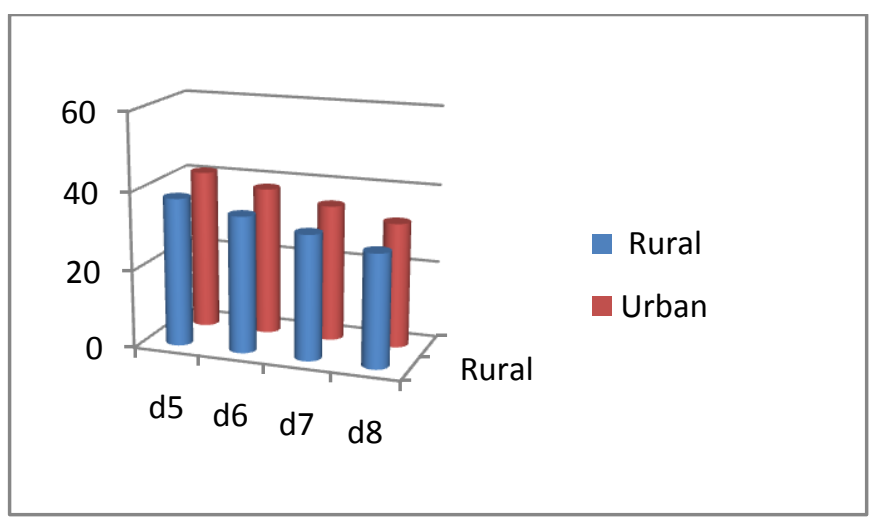

Figure 4: Describe accuracy percentage of rural and urban for dataset $d_{5}, d_{6}, d_{7}, d_{8}$

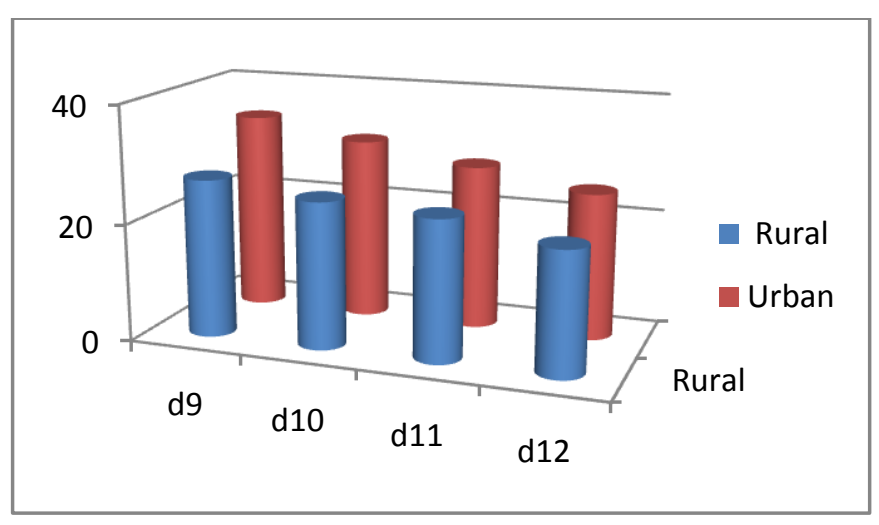

Figure 5: Describe accuracy percentage of rural and urban for dataset $d_{9}, d_{10}, d_{11}, d_{12}$ 


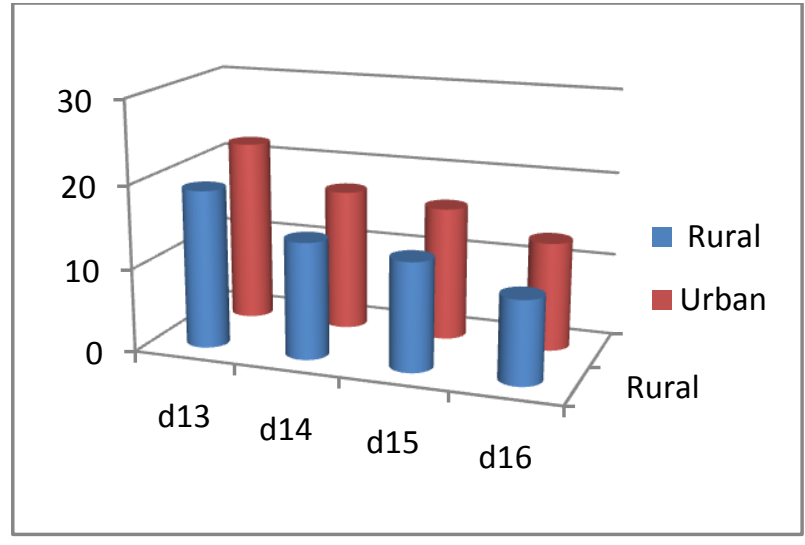

Figure 6: Describe accuracy percentage of rural and urban for dataset $d_{13}, d_{14}, d_{15}, d_{16}$

In figure 3 Describe accuracy percentage of rural and urban for dataset $\mathrm{d}_{1}, \mathrm{~d}_{2}, \mathrm{~d}_{3}, \mathrm{~d}_{4}$

In figure 4 Describe accuracy percentage of rural and urban for dataset $\mathrm{d}_{5}, \mathrm{~d}_{6}, \mathrm{~d}_{7}, \mathrm{~d}_{8}$.

In figure 5 Describe accuracy percentage of rural and urban for dataset $d_{9}, d_{10}, d_{11}, d_{12}$

In figure 6 Describe accuracy percentage of rural and urban for dataset $d_{13}, d_{14}, d_{15}, d_{16}$

\section{CONCLUSION}

This paper we conclude different users Internet usage in urban-rural area we find out urban area accuracy percentage are efficient and accurate compare to rural area it means the urban area have more aware with technology and we required e- system, e-technology, e-education in rural area to make efficient and accurate this model is provide better compare between the rural and urban collection.

\section{ACKNOWLEDGMENTS}

I, would like to thanks Professor M. U. Bokhari,(Chairman) from Aligarh Muslim University Department of Computer Science for this valuable suggestion and guidelines.

\section{REFERENCES}

[1] Bucur, C.M., 2002. Comer electronic, ASE, Bucharest

[2] Mâranu, R., 2012. Etapele Comerului electronic, Revista Tribuna Economic, no.1, pp.24

[3] International Journal of Electronic Commerce, 6(2), 3559.

[4] Lai, L.S.; Turban, E., 2008. Groups' formation and operations in the Web 2.0 environment and social networks. Group Decision and Negotiation, 17(5), 387402.

[5] C.R.C.E. (2000) Secretele comerului electronic.Ghid pentru exportatori-întreprinderi mici i mijlocii, International Trade Center, UNCTAD/WTO, Geneva.

[6] Anghel, L.D. 2002. Business to business marketing, Uranus, Bucharest.

[7] Gay, R. Charlesworth, A., Esen, R., 2007. Online marketing: a customer-led approach, Oxford, University Press Oxford.

[8] Anghelu, N.,2011. Comerul electronic, ASE, Bucharest. 